\title{
Feasibility and acceptability of computer based online certification program for frontline community health workers of Wardha district, India
}

\author{
Manoj S Patil', Abhay M Gaidhane², Shital Telrandhe ${ }^{3}$, Quazi Syed Zahiruddin, \\ Navnita Jadhav ${ }^{5}$ \\ ${ }^{1}$ Project Manager, ${ }^{5}$ Project Coordinator, Research Cell, Datta Meghe Institute of Medical Sciences University, \\ ${ }^{2}$ Professor and Head, ${ }^{4}$ Professor, Department of Community Medicine, Jawaharlal Nehru Medical College, \\ 3/T Consultant, Project Cell, Datta Meghe Institute of Medical Sciences University, Wardha, Maharashtra, India
}

\section{A B S T R A C T}

Background: In India, different types of Frontline Community Health Workers are recruited under different departments and health programmes. These include Anganwadi Workers (AWW) under ICDS, ASHA and ANMs under NRHM and health services. Training and recruitment of this staff cadre is an ongoing process. Most of the trainings are aimed at improving the knowledge and skills. A set of test is needed to assess the post training knowledge of trainees which should be feasible, acceptable and easy to administer. Team of Health Experts from DMIMSU, Wardha has developed such specific Computer based online certification tests which were administered to selected Frontline Community Health Workers engaged with DMIMSU. This study was conducted to assess the feasibility and acceptability of these tests. Aims and Objectives: 1] To assess the feasibility and acceptability of Computer based online certification tests for frontline workers. 2] To assess the scope for generalization of these tests to entire frontline health cadre of the district. Materials and Methods: Data was collected from 30 randomly selected Frontline Health Workers who were engaged in Community Outreach Activities/Projects of DMIMS and had undergone trainings and Online Certification tests. Questionnaire with Likert type scoring scale was administered. Data was compiled in MS Excel and Weighted Means and proportions of responses towards agreement and disagreement were calculated. Results: Average Weighted Mean was 4.07 showing Strong Agreement towards the feasibility and acceptability. Only $10.3 \%$ participants showed disagreement towards the feasibility and acceptability of this test whereas $89.7 \%$ participants showed agreement and among them, $47.67 \%$ showed strong agreement towards the feasibility and acceptability of this test. Conclusion: These tests were found quite feasible and well accepted by Frontline Health Workers. Similar tests should be made compulsory for all Frontline Health Workers Cadre and their performance in tests should be linked to provisions of incentives and seniority benefits.

Key words: Feasibility, Acceptability, Certification test, Frontline health workers

\section{INTRODUCTION}

According to WHO, "CHWs are men and women chosen by the community, and trained to deal with the health problems of individuals and the community, and to work in close relationship with the health services. They should have had a level of primary education that enables to read, write and do simple mathematical calculations" (WHO 1990). ${ }^{1}$ 
In India, different types of Frontline Community Health Workers are recruited under different departments/ programmes. These include Anganwadi Workers (AWW) under ICDS, ASHA and ANMs under NRHM and health services. In India, there are about 1293000 AWWs; 890000 ASHAs and 212185 ANMs. $^{2-4}$

Training and recruitment of this staff cadre is an ongoing process and frequent refresher trainings are conducted throughout the year as per the need or amendments in health schemes and programs. Most of the trainings are aimed at improving the knowledge and skills of these staff for specific tasks assigned. But assessments of these staff on knowledge for the specified tasks are an important component that is mostly ignored.

Keeping this in view, the team of Health Experts from DMIMSU, Wardha has developed specific Computer based online certification tests which were administered to selected Frontline Community Health Workers engaged with DMIMSU through different projects and Community Outreach Activities. These tests consisted 100 objective type questions with answerable options to be clicked on desktop screen and displayed results immediately on submission of the test. The questions displayed on the desktop screen were imported randomly from the data bank of about 300 questions on each topic of relevant training which was provided to FLWs. The test was programmed to present questions with shuffling of questions and options; also in graded levels of difficulty on passing through the previous level. Also the time limit for test is set and test gets automatically submitted after time limit is finished. Results appear immediately on the screen displaying information about Login ID, Name of participant, time of start and finish, total questions attempted, total correct answers, total score and result as Pass or Fail. This study was conducted-

1. To assess the feasibility and acceptability of Computer based online certification tests for frontline workers.

2. To assess the scope for generalization of these tests to entire frontline health cadre of the district.

\section{MATERIALS AND METHODS}

\section{Study area}

The study was undertaken in DMIMSU, Wardha. A number of Frontline Community Health Workers were engaged in Community Outreach Program of DMIMSU and were trained on different components of General Health and Maternal and child health through a series of trainings at DMIMS. From these groups, 10 Anganwadi Workers, 10 ASHA and 10 ANMs from different villages of Wardha district were randomly selected.

\section{Methodology}

Simple random sampling method was adopted for selection of study participants. Total 30 study participants were selected randomly, 10 each from the list of trained candidates in each cadre.

\section{Data collection}

Data was collected from selected Frontline Health Workers who were engaged in Community Outreach Activities/Projects of DMIMS and had undergone trainings and Online Certification tests. A written informed consent was taken from these workers. Each participant was provided with a sheet of questions list with scoring chart. Each question was supposed to be answered with a score marked on the scoring chart. The scoring chart for each question included scores from 0 to 5 where 0 indicated Strong Disagreement and 5 indicated Strong Agreement towards the sentence in question list. Each participant was explained the procedure of scoring in detail and then the test was administered. Average time required for administering questionnaire was approximately $30 \mathrm{~min}$; data collection was done by investigator himself during May-2015June-2015.

\section{Data analysis}

Weighted Means were calculated for scores assigned by respondents and Average Weighted Mean was calculated for overall questionnaire scores. Weighted Mean was interpreted as follows:

\begin{tabular}{ll}
\hline Weighted mean & Level of agreement \\
\hline$<1$ & Strongly disagree \\
$1.1-2.0$ & Slightly disagree \\
$2.1-3.0$ & Slightly agree \\
$3.1-4.0$ & Moderately agree \\
$>4.0$ & Strongly agree \\
\hline
\end{tabular}

Also proportions of respondents were calculated separately for showing disagreement, agreement and strong agreement.

\section{RESULTS AND DISCUSSION}

Overall, a strong agreement was found towards the feasibility and acceptability of this test with Average Weighted Mean of 4.07 (Table 1).

Only $10.3 \%$ participants showed disagreement towards the feasibility and acceptability of this test whereas $89.7 \%$ participants showed agreement and among them, $47.67 \%$ showed strong agreement towards the feasibility and acceptability of this test (Table 2). 
Table 1: Frequency distribution of scores assigned by respondents

\begin{tabular}{|c|c|c|c|c|c|c|c|}
\hline \multirow{2}{*}{$\begin{array}{l}\text { Questions } \\
\text { (Scores denoting } 0=\text { Strongly disagree; } 5=\text { Strongly agree) }\end{array}$} & \multicolumn{6}{|c|}{ Frequency of scores assigned } & \multirow{2}{*}{$\begin{array}{l}\text { Weighted } \\
\text { mean }\end{array}$} \\
\hline & 0 & 1 & 2 & 3 & 4 & 5 & \\
\hline Login and access to certification test was easy & 0 & 2 & 4 & 7 & 7 & 10 & 3.63 \\
\hline $\begin{array}{l}\text { Questions were readable, easy to understand and drafted } \\
\text { correctly in local language }\end{array}$ & 0 & 0 & 3 & 9 & 4 & 14 & 3.97 \\
\hline Answer options to objective type questions were relevant & 0 & 0 & 0 & 1 & 13 & 16 & 4.5 \\
\hline Marking answers to questions was very easy and time saving & 0 & 0 & 2 & 3 & 10 & 15 & 4.3 \\
\hline $\begin{array}{l}\text { It was possible to go through all } 100 \text { questions within allotted } \\
\text { time of test }\end{array}$ & 1 & 1 & 3 & 4 & 5 & 16 & 3.97 \\
\hline $\begin{array}{l}\text { Questions in the test covered all major and minor topics included } \\
\text { in the training modules }\end{array}$ & 0 & 0 & 0 & 2 & 11 & 17 & 4.5 \\
\hline $\begin{array}{l}\text { Copying answers from neighboring candidate was not possible } \\
\text { due to shuffling of questions and options }\end{array}$ & 0 & 1 & 3 & 5 & 6 & 15 & 4.03 \\
\hline $\begin{array}{l}\text { The test is easy and can be administered easily for all FLWs in } \\
\text { proper settings }\end{array}$ & 0 & 0 & 1 & 8 & 7 & 14 & 4.13 \\
\hline $\begin{array}{l}\text { Results were displayed immediately on clicking Submit button } \\
\text { after administering the test }\end{array}$ & 1 & 3 & 3 & 4 & 6 & 13 & 3.67 \\
\hline $\begin{array}{l}\text { Tests of this kind with graded difficulty levels will be acceptable } \\
\text { to all FLWs of your cadre }\end{array}$ & 0 & 1 & 2 & 6 & 8 & 13 & 4 \\
\hline Average & 0.18 & 0.82 & 2.1 & 4.73 & 7.36 & 13.45 & 4.07 \\
\hline
\end{tabular}

Table 2: Number and proportion of participants showing disagreement, agreement and strong agreement for specified test questions

\begin{tabular}{|c|c|c|c|c|c|c|}
\hline \multirow{2}{*}{$\begin{array}{l}\text { Questions } \\
\text { (Scores denoting } 0=\text { Strongly disagree; } 5=\text { Strongly } \\
\text { agree) }\end{array}$} & \multicolumn{2}{|c|}{ Disagree } & \multicolumn{2}{|l|}{ Agree } & \multicolumn{2}{|c|}{ Strongly agree } \\
\hline & Scores 0 to 2 & $\%$ & Scores 3 to 5 & $\%$ & Score 5 & $\%$ \\
\hline Login and access to certification test was easy & 6 & 20 & 24 & 80 & 10 & 33.33 \\
\hline $\begin{array}{l}\text { Questions were readable, easy to understand and drafted } \\
\text { correctly in local language }\end{array}$ & 3 & 10 & 27 & 90 & 14 & 46.67 \\
\hline Answer options to objective type questions were relevant & 0 & 0 & 30 & 100 & 16 & 53.33 \\
\hline $\begin{array}{l}\text { Marking answers to questions was very easy and time } \\
\text { saving }\end{array}$ & 2 & 6.67 & 28 & 93.3 & 15 & 50 \\
\hline $\begin{array}{l}\text { It was possible to go through all } 100 \text { questions within allotted } \\
\text { time of test }\end{array}$ & 5 & 16.7 & 25 & 83.3 & 16 & 53.33 \\
\hline $\begin{array}{l}\text { Questions in the test covered all major and minor topics } \\
\text { included in the training modules }\end{array}$ & 0 & 0 & 30 & 100 & 17 & 56.67 \\
\hline $\begin{array}{l}\text { Copying answers from neighboring candidate was not } \\
\text { possible due to shuffling of questions and options }\end{array}$ & 4 & 13.3 & 26 & 86.7 & 15 & 50 \\
\hline $\begin{array}{l}\text { The test is easy and can be administered easily for all FLWs } \\
\text { in proper settings }\end{array}$ & 1 & 3.33 & 29 & 96.7 & 14 & 46.67 \\
\hline $\begin{array}{l}\text { Results were displayed immediately on clicking Submit } \\
\text { button after administering the test }\end{array}$ & 7 & 23.3 & 23 & 76.7 & 13 & 43.33 \\
\hline $\begin{array}{l}\text { Tests of this kind with graded difficulty levels will be } \\
\text { acceptable to all FLWs of your cadre }\end{array}$ & 3 & 10 & 27 & 90 & 13 & 43.33 \\
\hline Total responses & 31 & 10.3 & 269 & 89.7 & 143 & 47.67 \\
\hline
\end{tabular}

$100 \%$ participants agreed that questions in the test covered all major and minor topics included in the training modules.

$96.7 \%$ participants agreed that the test is easy and can be administered easily for all FLWs in proper settings.

$90 \%$ participants agree that tests of this kind with graded difficulty levels will be acceptable to all FLWs of health cadre and $47.67 \%$ are in strong agreement towards the acceptability of this type of test (Table 2).

\section{CONCLUSION}

This test was found quite feasible and well accepted by Frontline Health Workers. It helped them well to assess their own knowledge gained through training and earmark the gaps in knowledge.

This type of test should be made compulsory for all Frontline Health Workers Cadre working in Public Health sector and knowledge on imparted training should be assessed at regular intervals. This will help to ensure the 
qualities of services they deliver are of appropriate level, to some extent. Their performance in this test should be linked with the Incentives and Seniority level on Service book.

\section{REFERENCES}

1. World Health Organization. The Primary Health Care Worker: Working Guide. WHO Geneva 1990.

2. Press Information Bureau, Govt. of India, Ministry of Women and
Child Development [Online] [Cited 2017 January16] Available on: http://pib.nic.in/newsite/PrintRelease. aspx?relid=121324.

3. Five years achievements and Initiatives (2009-2014); Ministry of health and family Welfare, Govt. of India; Page No. 9; [Online] [Cited 2017 January 16] Available on: http://nrhm.gov.in/images/ pdf/media/publication/five-years-of-nhm-2009-2014/5_years_ nhm_final.pdf.

4. Rural Health Statistics 2014-15, Ministry of health and family Welfare, Govt. of India; Page No. 12; [Online] [Cited 2017 January16] Available on: http://wcd.nic.in/sites/default/ files/RHS_1.pdf.

\section{Authors Contribution:}

MSP - Concept and design of the study, reviewed the literature, manuscript preparation and critical revision of the manuscript; AG \& QSZ - Concept, collected data and review of literature and helped in preparing first draft of manuscript; ST \& NJ - Conceptualized study, literature search, statistically analyzed and interpreted, collected data and review of study.

Source of Support: DMIMSU Wardha, Conflict of Interest: None declared. 